\title{
Industrial districts, inward foreign investment and regional development
}

\author{
Stefano Menghinello ${ }^{1,3}$, Lisa De Propris ${ }^{2}$ and Nigel Driffield ${ }^{3}$ \\ ${ }^{1}$ Istituto nazionale di statistica \\ (ISTAT) \\ ${ }^{2}$ Birmingham Business \\ ${ }^{3}$ Economics and Strategy Group \\ School \\ Direzione centrale statistiche \\ economiche strutturali \\ Sede di Via Anagnina \\ Via Cesare Balbo, 16 \\ 00100 Rome \\ Italy \\ The University of \\ Birmingham \\ Birmingham B15 2TT \\ UK \\ Aston Business school \\ Aston University \\ Birmingham B4 7ET \\ UK \\ menghine@,istat.it
}

\section{1.de_propris@bham.ac.uk}

\begin{abstract}
This paper compares the importance of agglomerations of local firms, and inward FDI as drivers of regional development. The empirical analysis exploits a unique panel dataset of the Italian manufacturing sector at the regional and industry levels. We explore whether FDI and firm agglomeration can be drivers of total factor productivity (separately and jointly), with this effect being robust to different estimators, and different assumptions about inter-regional effects. In particular, we isolate one form of firm agglomeration that is especially relevant in the Italian context, industrial districts, in order to ascertain their impact on productivity. In so doing, we distinguish standard agglomeration and localisation economies from industrial districts to understand what additional impact the latter has on standard agglomeration effects. Interaction effects between FDI spillovers and different types of agglomeration economies shed some light on the heterogeneity of regional development patterns as well as on the opportunity to fine tune policy measures to specific regional contexts.
\end{abstract}

JEL classification: O33, R58 


\section{Introduction}

The academic and policy debate on regional development has considered particular forms of firm agglomerations and foreign direct investment (FDI) as alternative and almost mutually exclusive drivers of regional economic growth. This distinction is most stark in the literature on Marshallian industrial districts (MIDs) which sees such agglomerations as endogenously driving local development, as it builds on existing industrial specialisations and knowledge endowments and it is fed by vibrant local entrepreneurship. Alternatively, foreign investment has traditionally been viewed as an exogenous source of employment opportunities or technology transfer. In this paper we seek to move beyond these rather limited views, and examine the joint effect of agglomeration and inward FDI on regional development.

Studies on agglomeration economies driven by endogenous forces have tended to focus on traditional manufacturing sectors, focussing on the collective core competences of local firms. The competitive advantage derived from firm clustering and intense local firms' interaction has led policy makers to target the latter as engines of regional growth.

On the other hand, foreign investment is seen as a source of new technology for a location, with a large literature focussing on the extent to which knowledge spills from the foreign firm to the host economy, thereby increasing productivity in the host economy (Driffield et al 2010). Regional policy-makers have shown much interest inward investment as a way of attracting world class manufacturing business, accessing frontier technology, and generating employment.

This dichotomy has recently become more blurred because FDI location choices have started to include also local industrial systems (LISs) especially for high value added functions; Dunning (2009) argues that such trend is expected to increase as "the pull of the geographical clustering and networking of related value-added activities will have an 
increasing effect on the choice of location by multinational enterprises" (p.26). In the most recent literature this has been referred to as knowledge or technology sourcing. This is discussed in an international business setting by Driffield and Love (2007), who highlight the importance of motivation for FDI in analysing the effects on the host economy. Equally, De Propris and Driffield (2006) highlight the links between technology sourcing FDI and the firm cluster literature.

This paper aims to extend the existing analysis of FDI localised spillovers by considering the impact of FDI and agglomeration\localisation economies on regional productivity, focussing on the case of Italy. The country presents an interesting case because it hosts many export oriented MIDs (Menghinello, 2004), and at the same time, its policies to attract FDI are relatively recent.

The novelty of this paper is that it explores the drivers of regional development across Italian regions by considering the impact of firm spatial agglomerations and FDI both separately and jointly. LISs, and in particular MIDs, in the Northern regions have been characterised by high levels of embedded technology, providing the greatest potential for attracting knowledge sourcing FDI (De Propris et al 2005). In contrast, the gains from FDI in the South may take the form of aggregate employment effects associated with the creation of relatively unskilled employment, but with little technological development.

The paper proceeds as follows. Section 2 introduces the debate by illustrating the link between regional development and agglomeration externalities. Section 3 illustrates the effects on regional performance induced by different forms of spatial agglomeration; while Section 4 describes the role of multinational enterprises (MNEs) as engines of regional externalities. Section 5 explores possible interaction between MNEs and IDs and their likely jointed effects on regional performance. Section 6 describes the data; Sections 7 and 8 introduce the model and illustrate the main results. Section 9 draws the final conclusions. 


\section{Agglomeration, externalities and regional development}

It is well understood that certain industries have a tendency to cluster in particular locations, gaining from agglomeration economies. These externalities are typically categorised as either technological or pecuniary, according to the mode by which the external benefits are appropriated. Pecuniary externalities related to the presence of a specialised labour market or connected to forward and backward linkages generated by the local market for intermediate goods, are considered to be more sensitive to geographical distance than technological externalities. Equally recent contributions to the economic literature also emphasise localised knowledge externalities as a primary source of regional development (Maskell et al., 1998). This is linked to an in-depth analysis of the local and global components in the process of knowledge creation (Antonelli, 2001).

The literature on regional development and externalities comprises both theoretical and empirical contributions. On the one hand, Grossman and Helpman (1991) demonstrate that geographically bounded knowledge externalities can generate a self reinforcing process that supports the creation of enduring dynamic comparative advantages, regardless of a country's or region's relative factor endowments. This is consistent with Markusen and Venables (1999), and the voluminous applied literature that has followed it, focussing on the relationship between external effects and the process of knowledge creation.

Feldman (1994) shows that spatial proximity plays a crucial role in defining the magnitude and geographical scope of knowledge spillovers. Indeed technological interaction among firms is deeply rooted in regional space, and regional-specific system of enterprise governance, institutions and values strongly affect firms' innovative performance. The tacit knowledge accumulated within the firm by means of learning processes is then significantly amplified by the local network of relationships involving other enterprises and institutions 
(Antonelli, 2001). Since firms increase the stock of knowledge by combining internal and external sources of learning and knowledge exchange, geographical proximity plays a crucial role in facilitating the knowledge exchanges and in increasing the complementarities among firms' innovation activities. This thus significantly boosts the systemic accumulation of knowledge, knowledge spillovers and systemic innovation processes (Audretsch and Feldman, 1996).

\section{Marshallian industrial districts and endogenous regional development}

It is well documented that the genesis and evolution of spatial clustering of economic activity generate different forms of firm agglomerations (Martin and Sunley, 2003). In particular, different forms of agglomerations generate different systemic economies (i.e. different magnitude and different tension between external, agglomeration and location economies).

A complex form of firm agglomeration is the MID, which emerges as a form of 'localised industry', populated by small firms and accounting for the majority of a locality's socio-economic activities (Becattini, 1990). Firms in MIDs tend to cooperate and coordinate their activities along the value chain, whilst developing complex sets of firm-specific and location specific intangible assets, embedded in a vibrant local business community. Such intangible assets, together with dedicated institutions, facilitate the functioning of inter-firm production relationships. Typically these are defined in terms of formal and informal codes of conduct and trade practices encouraging the emergence of "deliberate and purposeful" collective actions supported by forms of embedded and concerted local leadership (Bailey et al 2010; Scott and Storper, 1992; Storper, 1997). The ability of the system to reach collective solutions creates positive localised externalities leading to "collective efficiency", enhanced firm productivity (Schmitz, 1999) and a systemic innovation capacity (Helmsing, 2001). 
MIDs have mainly been studied in the context of manufacturing activities, so their capacity to act as engines of regional growth has been associated with location and agglomeration economies in the manufacturing sector (Becattini, et al 2009). Agglomeration economies are able to generate static externalities associated with specialisation and integration along the value chain, and to trigger processes of systemic learning and innovation that produce dynamic localised externalities. External economies are typically associated with systemic dynamic learning, through knowledge creation, transfer and sharing across the system of firms..

The competitiveness of MIDs is, therefore, agued to stem from the strong socioeconomic-institutional weaving of inter-firm relationships, imbued in well-established trust and social capital. As repositories of immobile, intangible and specialised knowledge, MIDs have increasingly attracted outside firms eager to access such know-how otherwise unreachable (De Propris, et al 2005; Herrigel, 2000).

The geographical distribution of MIDs across Italian regions is quite uneven, reflecting the uneven paths of economic development. Central and north-eastern regions are dominated by small scale entrepreneurship grouped in MIDs. North-western regions host most of Italy's large manufacturing firms characterised by scale economies and exogenous growth, as well as a large number of mature MIDs. Southern regions used to be dominated by public or private investments in footloose large plants, but they have recently experienced the emergence of small scale entrepreneurship in the form of emerging MIDs. Equally, FDI in Italy is concentrated in the North of the country. Figures $1 \mathrm{~A}$ and $1 \mathrm{~B}$ provide a representation of this. This distribution of FDI penetration across industries is provided in the Appendix 1.

Figures $1 \mathrm{~A}$ and $1 \mathrm{~B}$ here. 


\section{Inward FDI and regional development}

The empirical literature on the contribution of FDI to host country productivity tends to focus on productivity spillovers, and with the impact of newer, more productive firms increasing average productivity (Aitken and Harrison, 1999). Much of the early literature on the nature of spillovers from inward investment is summarised in Driffield (2006), as is the econometric treatment of both intra-industry and inter-industry regional spillovers. The underlying hypothesis, as the theme of this special edition notes, is the OLI paradigm of Dunning (1979). Equally, as other strands of the FDI literature has pointed out, the decision to engage in FDI may be driven by other factors, notably technology sourcing, as discussed in the context of clustering and location by De Propris and Driffield (2006). Geographical proximity facilitates linkages between MNEs and domestic firms, and encourages spillovers in a number of ways. In the short term these may take the form of buyer-supplier relationships, but in the long term may include movement of labour between the foreignowned and domestic sectors.

This analysis builds on work that has already highlighted the importance of locality when examining the growth effects of FDI. Indeed, in more general terms this builds on Dunning (1998) and the subsequent literature on the importance of location in the impacts of FDI. Cantwell and Piscitello (2005) have investigated respectively spillover effects associated with the location of R\&D activities across EU regions. Driffield (2006) provides substantial empirical evidence on the presence of localised spillovers from FDI. This literature highlights two salient points. Firstly, that there are productivity growth effects from FDI, but, secondly, that these are often dependent on other phenomena, such as absorptive capacity (Girma, 2005) or the motivation of the inward investors to enter a particular location (Driffield and Love, 2007). This also highlights the importance of the location-specific characteristics, when evaluating the impacts of FDI, and indeed growth dynamics more generally. 
However, in addition to the beneficial effects of FDI, the literature also refers to a "crowding out effect". Sembenelli and Siotis (2008) discuss this in detail in the context of Spain, interpreting a negative relation between inward investment and domestic productivity as suggestive of increased output by the foreign sector leading to a reduction in the scale of the operations by the domestic competitors.

\section{MIDs and MNEs as joint drivers of regional development}

While the literature on the interactions between spatial agglomerations and inward investment is still developing, there are some isolated contributions. Some look at large firms in MIDs and stress that, in order to access local and tacit knowledge, large firms -including MNEs- must embed themselves in the local system of firms (Bellandi, 2001; Dupuy and Gilly, 1999). More recently, De Propris and Driffield (2006) provide substantial evidence that intra-industry and inter-industry spillovers between the foreign-owned and domestic sectors of the host economy are greatest in cluster-intensive regions. In parallel, De Propris et al (2005) find that the FDI chooses to locate within MIDs for their competitive advantage in specialised knowledge and strong export performance.

The above literature, however, offers little in the way of empirical analysis of the relationships between inward investment, agglomeration and productivity. Driffield and Munday (2000) provide some preliminary empirical evidence on the role played by agglomeration economies in FDI spillovers and show that both individually contribute to the comparative advantages of manufacturing industries in the UK. In particular, although they argue that agglomeration may magnify the spillover effects from FDI, they also show that high levels of agglomeration of domestic activities could deter foreign entry. Driffield and Love (2003) also find evidence that spatial agglomeration positively affect reverse-spillovers. Head et al. (1995) emphasise the relevance of agglomeration economies for foreign entry. 
Cantwell and Piscitello (2005) show that different typologies of localised externalities strongly affect MNEs' location choice across European regions.

However, none of the above contributions has tested the joint effect of different types of spatial agglomeration and FDI on regional productivity: this is the novelty of this paper.

\section{The Data}

The dataset used in this paper is a panel stratified by region, industry and time. It covers the 20 (NUTS 2) regions of Italy, across 16 (NACE 2) manufacturing sectors for the period 1993-2001 (odd years only) up to a total of 1,500 observations. The dataset combines information from different sources at the regional and industry levels, including (a) regional business data from official statistics produced by the Italian statistical Institute (ISTAT) (b) a national FDI database set up and maintained by the Polytechnic University of Milan; (c) spatial agglomeration indicators calculated from territorial data and territorial classification supplied by ISTAT.

The three FDI variables, FSIR, FSI and FSR, capture inward investment, and are based on the share of foreign over total employment. In particular, they measure respectively FDI within a sector and a region, within a sector across all regions, and within a region across all sectors. They therefore seek to capture regional intra-industry effects, national intraindustry effects and regional inter-industry effects. On the other hand, the AGR and AGIR variables detect standard agglomeration economies and localised economies, respectively. AGR captures a region's manufacturing intensity, namely its density of related or unrelated manufacturing sectors. On the other hand, localised externalities capture a region's industrial specialisation.

In addition, we single out a form of LISs typical of Italy, industrial districts. We rely on a standard map of Italian MIDs (ISTAT 2001, Sforzi 2009) and we construct two 
variables: BIDs refers to MIDs that are made up of SMEs (firms with up to 250 employees), whereas SIDs refers to MIDs dominated by small firms (firms with less than 50 employees). This distinction, well accepted in the current literature (Sforzi, 2009), enables us to explore whether firm size affect the ability of MIDs to generate productivity gains via the way they interact with FDI and agglomeration economies. ${ }^{1}$

All monetary variables are expressed in real terms (2000 prices), using proper price index deflators. A complete list of variables is included in Table 1.

Table 1 here

\section{Modelling externalities in productivity}

The literature on the estimation of productivity externalities is well developed and well understood. As we discussed above it is based on the fundamental principles of endogenous growth and adopts a relatively standard model of total factor productivity with externalities. Griliches and Mairesse (1995) stress the advantages of panel data for estimating productivity growth.

This employs an augmented production function of the form:

$$
\ln Q_{i r t}=a+\beta_{1} \ln K_{i r t}+\beta_{2} \ln L_{i r t}+\mu t+\sum_{k=1}^{p} \alpha_{k} X_{i r t}+u_{i r t}
$$

Where Q, K, L represent output, capital and labour of the firm or sector respectively, and $\mathrm{X}$ represents a vector of potential externalities. This expression also includes a time trend (t) as a proxy for exogenous technological change. Model variables have three subscripts industry (i), region (r) and time (t) - corresponding to a panel dataset with the regional

\footnotetext{
${ }^{1}$ While MIDs and other forms of LIS can be identified at the sub-regional level, more detailed analyses of output, capital and labour are not available at this level is aggregation.
} 
industry as the reference unit of analysis. In particular, the error term of the panel model can be specified as the sum of respectively an individual regional industry effect and a random error:

$$
u_{i r t}=\alpha_{i r}+\varepsilon_{i r t}
$$

With spatial data of this type, it again widely acknowledged that one has to capture inter-regional output spillovers, omission of which will bias upwards the $\alpha_{k}$ terms. If we consider spatial dependence across regions, the model expression can be reformulated as

$$
\ln Q_{i r t}=a+\lambda W_{r} \widetilde{Q}_{i r t}+\beta_{1} \ln K_{i r t}+\beta_{2} \ln L_{i r t}+\beta_{3} S_{r}+\mu t+\sum_{k=1}^{p} \alpha_{k} X_{i r t}+\alpha_{i r}+\varepsilon_{i r t}
$$

Where $\mathrm{W}_{\mathrm{r}}$ is a regional contiguity matrix of known constants which inform us of the output of adjacent regions in the same industry and $\lambda$ is the spatial-autoregressive coefficient. In particular, the regional contiguity matrix adopts a binary spatial metrics, by which $\mathrm{w}_{\mathrm{ij}}=1$ if regions $\mathrm{i}$ and $\mathrm{j}$ share a border and 0 otherwise, and interaction between regions is limited to first-order proximity. This captures the most popular form of regional interdependence in the framework of panel data models stratified by industry, region and time. As a result, the spatial-autoregressive coefficient accounts for general inter-regional externalities not directly considered by the externality vector. In addition we include a term to capture the size of the region $\mathrm{S}$, which captures the regions share of the total population. This captures other forms of externalities related to the region, particularly those generated from demand side effects. We then augment the standard regional productivity model with the FDI measures (FSIR, FSI, FSR) and four types of agglomeration related variables (AGR, AGIR, BID and SID). ${ }^{2}$

The final equation is therefore specified as:

$$
\begin{aligned}
& \ln Q_{i r t}=a+\lambda W_{r} \widetilde{Q}_{i r t}+\beta_{1} \ln K_{i r t}+\beta_{2} \ln L_{i r t}+\mu t++\alpha_{1} F S I R_{r t}+\alpha_{2} F S I_{i t} \\
& +\alpha_{3} F S R_{r t}+\alpha_{4} A G R_{r t}+\alpha_{5} A G I R_{r t}+\alpha_{6} A G I R_{r r} * B I D_{i r}+\alpha_{7} A G I R_{r t} * S I D_{i r}+\alpha_{i r}+\varepsilon_{i r t}
\end{aligned}
$$

\footnotetext{
${ }^{2}$ See Appendix 1 for the correlation matrix.
} 
Variables FSIR, FSI and FSR capture the overall impact of MNE activities on regional productivity, while AGR, AGIR, BID and SID capture dimensions of endogenous spatial agglomeration. In order to test for potential synergies between the FDI and the agglomeration effects, we introduce interaction effects between FSIR and AGR, AGIR, BID and SID into the model. ${ }^{3}$

The estimation of a static panel data model stratified by region and industry and with a spatial-lag term, suggests a number of econometric issues. A modified Wald test for groupwise heteroscedasticity on the residuals is employed. The null hypothesis of homoscedasticity is strongly rejected, albeit that this test is known to have low power in the context of fixed effects panel data model with large N and small T. Several autocorrelation tests were also carried out, providing mixed conclusions on the presence of auto-correlation ${ }^{4}$. However, the presence of first order serial autocorrelation in the idiosyncratic residuals of the model is detected.

Following Pesaran (2004) the diagnostic checking of the fixed effects panel data model also includes the testing for cross section dependence, with respect to both the regional and the industry dimensions of the panel. In particular, two different tests are used to detect spatial dependence. The first is a first order spatially lagged error term test that uses a Moran (1948) approach to define the regional contiguity matrix. The second test for spatial dependence, developed by Pesaran (2004), also allows the testing of cross section dependence across industries. As reported in Table 2, all these tests provide substantial evidence of spatial as well as industry dependence plaguing the data.

\footnotetext{
${ }^{3}$ The inclusion of external effects into the model raises a number of potential methodological and estimation problems. In the applied industrial economics literature, there is a long standing debate on the extent to which externalities can be correctly identified and measured. Driffield et al. (2004) highlight that the presence of a properly identified spatial dependence structure in a regional model allows genuine spillovers to be distinguished from demand effects. Finally, collinearity problems may emerge when a large number of external effects are included in the model.

${ }^{4} \mathrm{~A}$ Wald test type for serial correlation in the idiosyncratic errors of a linear panel data model, discussed by Wooldridge (2002), was applied. seem to partially contradict previous results by not providing additional statistical evidence on the presence of serial correlation.
} 
The presence of substantial violations in the error term assumptions of the fixed effects panel data model are very likely to alter the statistical properties of LSDV estimators. As a result, more robust estimation methods are carried out. These estimation techniques include the first order autocorrelation panel data model developed by Baltagi and Wu (1999), feasible generalised least squares (FGLS) estimators, panel corrected standard error (PCSE) estimates or Prais-Winsten regression. These estimators progressively relax the assumptions about heteroscedasticity across the panels and autocorrelation within the panels. Once the Prais-Winston technique is used, and the contiguity matrix is included, there are no problems of spatial error, or the industry level equivalent.

\section{Results}

The main results are summarised in Tables 2-5. Table 2 shows that the results concerning externalities are robust to the different estimation methods. Importantly the introduction of a spatially lagged dependent variable and of an additional externality variable -represented by regional size- does not affect the statistical significance of FDI and agglomeration externality effects. This is vital for our findings on region externalities, as it shows that the results are not driven by spurious correlation, or an omitted variable bias related to other sources of externality effects. This is discussed in detail in the context of externalities more generally in Driffield (2006). We also test for spatial error, and find no evidence of it. This suggests that there are no other inter-regional effects that are not being captured, in the FDI terms for example.

We find significant evidence of standard agglomeration economies, localisation economies and intra-industry FDI effects, see Table 2. The results suggest that inward FDI generates a productivity increase, but this effect is limited to the sector of the investment. This is consistent with FDI motivated by sector-specific knowledge, in that local firms are able to 
assimilate the knowledge transferred from the foreign firm, thereby generating productivity growth within the sector.

Further, there are statistically significant agglomeration effects in regional productivity. While standard agglomeration economies (AGR) contribute the most to TFP, localisation economies (AGIR) spillovers are also important. The positive and significant coefficients on the variables capturing agglomeration and localisation economies suggest that regional performance is related to firms' agglomeration.

Table 2 here

The differing results in terms of the agglomeration and localisation effects warrant further investigation. In order to do this we initially distinguish between the different regions of Italy, focussing on the Prais-Winsten estimator as the most robust. ${ }^{5}$

We extend this analysis further in two ways: we first distinguish northern and southern regions; and then regions with high/low FDI penetration. The contrast between Northern and Southern Italy is well understood in terms of industrial make-up and income. The North is more industrialised especially in high-tech and high-value added manufacturing industries which contribute to Italy's overall international competitiveness. By contrast, southern regions have shown a delayed industrialisation mostly driven by public subsidies through large scale investment, nevertheless more recently some forms of small scale entrepreneurship has emerged still though with below average productivity and lower levels of technological intensity. Differences between the North and South are demonstrated by large differences in manufacturing density, productivity, innovation and export propensity. They also reflect large

\footnotetext{
5 This is used to produce panel corrected standard error (PCSE) estimates, where the disturbances are, by default, assumed to be heteroskedastic and contemporaneously correlated across panels. In particular, it is assumed that within panels, there is first-order autocorrelation and that the coefficient of the AR(1) process is specific to each panel. In addition, for each element in the covariance matrix, all available observations (time periods) that are common to the two panels contributing to the covariance are used to compute the covariance.
} 
differences in capital intensity, and may reflect a structural break in terms of our productivity estimation. Within the South, it is also noticeable that there are large variations location patterns of firms, mobile capital is attracted to the south by tax incentives. In contrast, in the North location patterns are much less heterogeneous within the Northern region, and large firms tend to be embedded, while small and medium generally cluster in Industrial districts.

The results comparing the North and South of Italy illustrate clearly that northern regions tend to be more capital intensive and southern regions more labour-intensive as it is well accepted (Table 3). Our findings highlight the productivity gains that made at the sector level as a result of Inward FDI, across both northern and southern Italian regions. The differential impacts of FDI can be seen, however, with respect to the regional effects. FSIR is positively related to productivity in the northern regions, with higher levels of absorptive capacity by local firms and a better ability to assimilate technology transfer from FDI within a given regional industry. However, FDI regional effects across industries are negative for northern regions due to congestion and crowding out effects, but positive for southern regions. The latter suggests that in the least developed parts of the Italian economy, FDI is an additional driver of productivity improvement to the one activated domestically and it contributes to its industrial development.

Once one allows for regional size, agglomeration effects are still important in productivity. Agglomeration and localisation economies are strong in both parts: manufacturing intensity is more important for southern regions as regional growth depends on the expansion of a manufacturing base, whereas localised industrial specialisation is more relevant for northern regions which, as advanced industrial systems, own their competitive advantage to a high degree of specialisation and knowledge intensity. MIDs characterised by a more fragmented production organisation and smaller industrial plant size-SIDs- appear to have a negative effect on the level of regional productivity in southern regions. In contrast, 
BIDs, as MIDs characterised by the presence of relatively larger companies, positively impact regional productivity in southern regions. In the same way, we find evidence of the important contribution of BIDs to regional productivity (see Tables 4 and 5), as an additional effect with respect to both agglomeration and localisation externalities.

BIDs are an emerging phenomenon and our findings shed some light on their role for regional development. This is consistent with a growing literature that is looking at how small size is hindering firms' ability to address the challenges of technological change and globalisation, despite the benefits of co-location above discussed. Recent evidence (Mariotti and Mutinelli 2003) suggests that firms within MIDs operate on a much larger scale achieved either through internal growth or through the creation of groups of firms. Both strategies strengthen firms' capacity to invest, to be innovative and to explore new markets. Despite the larger size and the more complex structure, firms remain rooted in their districts, so that they can both benefit from localisation and agglomeration economies that belonging to a MIDs ensures, as well as achieve some scale economies on, for instance, marketing or innovation technology.

Table 3 here

In order to further investigate the links between inward investment and agglomeration, we divide the sample into regions with high and low levels of FDI. In essence this can be thought of asking the question whether increased agglomeration in the absence or presence of FDI increases productivity. We divide Italian regions at the average depending on whether they have low or high FDI penetration. Following Sutton's (1996) analysis of endogenous sunk costs, this can also be thought of as treating FDI as endogenous, and examining the impact of agglomeration given the level of FDI ( Table 4). 
Table 4 here

In regions with already high levels of FDI, additional FDI generates productivity effects at the regional and industry levels (FSIR). This seems to suggest that a critical mass of FDI should be reached at the regional level, before localised intra-industry spillovers can take place. However, there is evidence of possible congestion and crowding out effects leading to a decline in productivity since the FDI regional effect is negative ${ }^{6}$. At the same time the industry effect is positive and significant, suggesting that intra-industry FDI externalities impact positively on regional productivity. The impact of FDI is greater for regions with low FDI penetration, both at the regional and industrial levels, suggesting that FDI generates growth and catching up in regions with less inward investment. Agglomeration effects are also strong for both sets of regions, in particular in relation to the presence of localisation economies - industrial specialisation and the role of BIDs. Indeed we find here again further confirmation of the heterogeneous impact of MID on regional development. While BIDs show a positive contribution to regional productivity, SIDs have a negative impact, for the reasons above mentioned. This result is consistent across the two sets of regions.

Finally, we explore the presence of potential synergies between FDI spillovers and agglomeration externalities by including a set of interaction terms in the baseline model and repeating the estimation. The full set of findings on the interaction terms between FDI and agglomeration effects is presented in Table 5. The coefficients on the terms in the base line model are robust with the inclusion of the interaction terms, so for brevity we summarise the results for the additional terms only. The detailed sub-regional analysis is aimed to understand

\footnotetext{
${ }^{6}$ For more discussion on this see Aitken and Harrison (1999) and the large literature that is based on this argument.
} 
the synergies between FDI effects and the MIDs effects jointly: in particular, it distinguishes northern and southern regions; regions with low/high AGR and high/low FDI penetration.

Table 5 here

In the northern regions the joint MID and FDI effect is very strong and positive (see Table 5A). These regions include central and northern MIDs usually associated with the Third Italy. However, in the South, there is no such effect. Indeed, interactions between agglomeration and FDI in the south produce adverse effects. This suggests that in such cases, large foreign investors (often with large subsidies) come to dominate regions where local firms are small and markets are thin. The inward investment generates crowding out, both in goods and factor markets (being able to attract the best labour, and obtaining better terms from suppliers for example), leading to a fall in output and productivity in the host country sector.

Table 5B summarises the impact of the interactions between FDI and low/high FDI and low/high AGR taken separately. The interaction effect of FDI and agglomeration, in particular MID, is unsurprisingly only relevant for those regions which experience a high degree of FDI penetration: here the joint effect is related to FDI and a dense manufacturing base (AGR), and the presence of SIDs and BIDs. Manufacturing intensive regions -also populated by MIDs- show a strong and positive interaction effect between FDI and MID, both BIDs and SIDs, however there is some crowding out effect at the lever of industrial specialisation. For low manufacturing intensive regions, only the interaction between industrial specialisation of FDI generates a positive impact on regional productivity. This suggests that regional growth benefits from an FDI that is matched with a degree of local 
specialisation which is in line with findings elsewhere on the importance of the host economy being able to create local linkages with the foreign investor.

Finally, in Table 5C we pair regions with low/high AGR and high/low FDI penetration and identify four regional groups. Group A includes regions that are manufacturing intensive and experience a high FDI penetration; they coincide with regions that are specialised in scale economy sectors. For these the interaction effects of FDI with AGR, SID and BID are all positive, suggesting that regional productivity benefits from the presence of MIDs and sector diversity and specialisation in conjunction with high FDI penetration. The interaction effect between AGIR and FSI is negative due to crowding out effect. Group B regions manufacturing intensive with low FDI- on the other hand seems to jointly benefit from regional specialisation and FDI: this can be explained by the fact that FDI targets specialised technology which is abundantly present in these regions. Group $\mathrm{C}$ regions could be classifies as laggards, since they have low FDI and a poor manufacturing environment. For these regions the interaction effect between FDI and AGR is negative due to displacement, resource pouching. The potentially fast growing regions of Group D -low manufacturing intensity but high FDI penetration- show positive interaction effects between FDI and both AGIR and SID: so FDI targeted at MID specific sectors seems to positively impact on regional growth. The results based on these more complex interactions of FDI and agglomeration are summarised in Figure 2.

Figure 2 here

\section{Concluding remarks and policy recommendations}

The paper provides evidence of the impact on regional development of specific forms of firm spatial agglomerations and inward FDI, when these are considered both separately and 
jointly. As Dunning (1998) famously pointed out, location is often under-considered in IB, and seen merely as a way to explain the spatial distribution of firms. In line with this special issue, the paper aims to overcome the limits and to coalesce the location-based regional growth literature with the large stream of the IB literature concerned with the national or regional impacts of the inward FDI. The former tends to view agglomeration as an endogenous form of development exclusively driven by local actors, while the latter seeks agglomeration as an exogenous determinant of inward FDI. This paper reconciles these issues, and provides evidence that interactions between the two phenomena are conceptually sound and empirically measurable.

Much of the international business literature on spillovers from FDI focuses on the extent to which the firm is a vehicle for international technology transfer. The empirical findings presented here shown that while inward FDI does generate a productivity increase in the home country. Specifically, locations with higher levels of agglomeration and a significant degree of local industry specialisation are those best placed to benefit from inward investment and the associated new technology.

Perhaps our most significant finding is that the greatest benefits to productivity occur with the interaction between FDI and MIDs: in particular, we find that MIDs with large firms that attract FDI generate the greatest productivity growth. Our results suggest the presence of potential synergies, in effect additional externalities, stemming from the co-localisation and potential interaction of MNEs with different kinds of agglomeration economies can be derived from the empirical testing of a wide range of interaction effects. FDI externalities positively interact with localised industry externalities, increasing TFP level of regional industries. However, our results also suggest that the benefits are felt more widely than within the location of the investment. 
The analysis presented here shows that the very simple portrait of strategies of regional development, contrasting endogenous development of (smaller) national firms and exogenously determined FDI, is erroneous. Rather, we emphasise the choice of location, and the impact on the host economy of FDI deciding to locate inside MIDs. Technology seeking strategies means that the strongest productivity effects from FDI occur within the industry of the investment attracted by areas of dense manufacturing and hubs of specialisation.

Our analysis adds new stimuli to the current debate on the importance of FDI for local development. FDI is not only attracted by firm clustering, but in particular by MIDs, arguably to source the most from their locally embedded and often tacit knowledge. The technology sourcing motivation of FDI is confirmed by their penetration in MIDs in medium or high technology sectors, where there is a balance between small and larger size firms. At the same time, FDI can transfer frontier technology to firms in MIDs nourishing their learning thanks to the levelled technology knowledge.

Our results suggest that inward FDI can play such a role and be a source of cutting edge knowledge for firms well embedded in MIDs (see Becattini et al 2009). If industrial policy was to pro-actively attempt to attract FDI, our findings suggest that such an initiative has to remain focused and selective by capturing those foreign firms that complement existing local industries to maximise the chance of synergies and mutual benefit.

Policies that encourage and support MIDs ought therefore to reflect a mix of concerns linked to the place (institutional framework and civic society), the industry and the positioning of the latter on the international technology frontier. Crucially, we find that the positive synergies that emerge between MID and FDI in terms of productivity for the host economy, depend on the technology literacy of the latter, therefore a cluster-based industrial policy should aim at strengthening endogenous and systemic processes of innovation in such industries. 
Finally, the paper shows that regions are complex nexus of "untraded interdependencies" where the complexity of knowledge-based interactions between local and global actors matter much more for their ability to be able to compete in the global economy than standard industry characteristics.

\section{References}

Aitken, B. J. and Harrison, A. E. (1999) Do Domestic Firms Benefit from Direct Foreign Investment? Evidence from Venezuela, American Economic Review, 89: 605-18.

Antonelli, C. (2001) The microeconomics of technological systems. Oxford: Oxford University Press.

Audretsch, D.B. and M.P. Feldmann (1996) Innovative clusters and the industry life cycle, Review of Industrial Organization, 11:253-73.

Bailey D., Bellandi M., Caloffi A. and De Propris L. (2010) Place-renewing leadership: trajectories of change for mature manufacturing regions in Europe, Policy Studies, forthcoming.

Baltagi B. and Wu P. (1999) Unequally Spaced Panel Data Regressions with AR(1) Disturbances, Econometric Theory, 15.

Becattini, G. (1990) The Marshallian industrial district as a socio-economic notion in: F. Pyke, G. Becattini and W. Sengenberger (Eds), Industrial Districts and Inter-firm Cooperation in Italy, 37-51,Geneva, International Institute for Labour Studies.

Becattini, G., M. Bellandi, and L. De Propris (2009) A Handbook of Industrial Districts, Edward Elgar: Cheltenham.

Bellandi, M. (2001) Local development and embedded large firms, Entrepreneurship and Regional Development, 13(3):189-210

Camagni R. P. (1995) The concept of innovative milieu. Its relevance for public policies in European lagging regions, Papers in Regional Science, 74:317-340.

Cantwell, J.A. and Piscitello, L. (2005) Recent location of foreign-owned R\&D activities by large multinational corporations in the European regions: the role of spillovers and externalities, Regional Studies, 39 (1): 1-16. 
Cohendet, P., Kern, F., Babak, M. \& Munier, F. (1999) Knowledge coordination, competence creation and integrated networks in globalized firms, Cambridge Journal of Economics, 23(2): $225-242$.

Combes, P.P. Duranton, G., Overman, H.G. (2005) Agglomeration and the adjustment of the spatial economy. Papers in Regional Science 84 (3): 311-349

De Propris L. and Driffield N. L. (2006) The Importance of Cluster for Spillover from FDI and Technology Sourcing, Cambridge Journal of Economics, 30(2): 277-291.

De Propris, L., Driffield, N. and Menghinello, S. (2005) Local Industrial Systems and the Location of FDI in Italy, International Journal of the Economics and Business, 12 (1):105-21.

Driffield, N.L. (2006) On the search for spillovers from FDI with spatial dependency, Regional Studies, 40(2): 107-119.

Driffield, N. L. and Love, J. H. (2003) 'Foreign Direct Investment, Technology Sourcing and Reverse Spillovers', The Manchester School, 71, 659-72.

Driffield, N. and Love, J. (2007) Linking FDI motivation and host economy productivity effects: conceptual and empirical analysis, Journal of International Business Studies, 38 (2): 460-473.

Driffield, N Love, J.H. and Menghinello, S. (2010) The Multinational Enterprise as a Source of International Knowledge Flows: Direct Evidence from Italy. Journal of International Business Studies,. 41 (2) pp. 350-359

Driffield, N.L. and Munday, M.C. (2000) Industrial performance, agglomeration, and foreign manufacturing investment in the UK, Journal of International Business Studies, 31(1): $21-37$

Driffield, N.L. Munday, M. and Roberts, A. (2004) 'Inward investment, transactions linkages, and productivity spillovers.' Papers in Regional Science, Vol. 83 (4), pp. 699-722.

Drukker, D.M. (2003) Testing for serial correlation in linear panel-data models. The Stata Journal (3)2: 1-10.

Dunning J.H. (2009) Location and the multinational enterprise: John Dunning's thoughts on receiving the Journal of International Business Studies 2008 Decade Award, Journal of International Business Studies, 40: 20-34.

Dunning, J. H. (1979) Explaining Patterns of International Production: in Defence of the Eclectic Theory, Oxford Bulletin of Economics and Statistics, 41: 269-95.

Dunning, J.H. (1998) Location and the Multinational Enterprise: A Neglected Factor?, Journal of International Business Studies, 29: 45-66. 
Dupuy, C. and Gilly, J.-P. (1999) Industrial groups and territories: the case of Matra-MarconiSpace in Toulouse. Cambridge Journal of Economics, 23: 207-23

Enright, M.J. (2000) Regional Clusters and Multinational Enterprises, International Studies of Management and Organisation, 30 (2): 114-38.

Feldman, M.P. (1994) The Geography of Innovation. Dordrecht: Kluwer Academic Publishers.

Fosfuri, A. and Motta, M. (1999) Multinationals without advantages, Scandinavian Journal of Economics, 101(4): 617-630.

Girma, S. (2005) Absorptive Capacity and Productivity Spillovers from FDI: A Threshold Regression Analysis, Oxford Bulletin of Economics and Statistics, 67 (3): 281-306.

Griliches, Z. and Mairesse, J (1995) 'Production functions: the search for identification', NBER working paper 5067.

Grossman, G.M. and Helpman, E. (1991) Innovation and Growth in the Global Economy. Cambridge, MA: MIT Press.

Head K., Ries J. and Swenson D. (1995) Agglomeration benefits and location choice: evidence from Japanese manufacturing investments in the United States, Journal of International Economics, 38: 223-47.

Helmsing, A.H.J. (2001) Externalities, Learning and Governance: New Perspectives on Local Economic Development. Development and Change, 32: 277-308

Herrigel, G (2000) Large firms and industrial districts in Europe. In Dunning, J.H. (ed) Regions, globalization, and the knowledge-based economy. Oxford University Press, Oxford.

ISTAT. (1997) I sistemi locali del lavoro, 1991. Roma: Collana Argomenti.

Mariotti, S. and Mutinelli, M. (2003) Home country employment and foreign direct investment: evidence from the Italian case, Cambridge Journal of Economics, 27: 419431.

Markusen, J. and Venables, A. J. (1999), "Foreign Direct Investment as a Catalyst for Industrial Development.” European Economic Review 43 pp.335-356.

Martin R. and Sunley P. (2003) Deconstructing clusters: chaotic concept or policy panacea?, Journal of Economic Geography 3:5-35.

Maskell, P., Eskelinen, H., Hannibalsson, I., Mamberg, A., and Vatne, E. (1998). Competitiveness, localised learning and regional development: Specialisation and prosperity in small open economies. London: Routledge. 
Menghinello, S. (2004) Local engines of international trade: the case of industrial districts in Italy. In (eds) Cainelli, G. and Zoboli, R. (eds.) Inside the industrial district, The Evolution of Local Capitalism in Italy. Contribution to Economics. Heidelberg: Physica Verlag. pp. 319-35.

Moran, P.A.P. (1948) The Interpretation of Statistical Maps. Journal of the Royal Statistical Society, Series B, 10 (2): 243-51.

Oulton, N. (1996) 'Increasing Returns and Externalities in UK Manufacturing: Myth or Reality?', Journal of Industrial Economics, 44: 99-113.

Pesaran, M.H. (2004) General Diagnostic Tests for Cross Section Dependence in Panels. Cambridge Working Papers in Economics 0435, Faculty of Economics, University of Cambridge.

Rabellotti, R. (1999), Recovery of a Mexican cluster: devaluation Bonanza or collective efficiency, World Development, 27 (9): 1571-85.

Santangelo, G.D. (2004) FDI and local capabilities in peripheral regions - The Etna Valley Case. Transnational Corporations, 13 (1): 73-106.

Sembenelli, and G. Siotis (2008), Foreign Direct Investment and Mark-up Dynamics: Evidence from Spanish Firms, Journal of International Economics, 76, 107-115.

Schmitz, H. (1999), Collective efficiency and increasing returns, Cambridge Journal of Economics, 23 (4), 465-83.

Scitovsky, T. (1954), Two concepts of external economies, Journal of Political Economy, 62: $143-51$.

Scott, A. J. and Storper, M. (1992) Regional Development Reconsidered, in H. Ernste and V. Meier, (EDS) Regional Development and Contemporary Industrial Response: Extending Flexible Specialization. pp. 3-24. London and New York: Bellhaven Press. Sforzi, F. (2009) The Empirical Evidence of Industrial Districts in Italy, in Becattini, G., M. Bellandi, and L. De Propris (2009) A Handbook of Industrial Districts, Edward Elgar: Cheltenham.

Storper, M. (1997), The Regional World, New York and London: The Guilford Press.

Sutton, J. (1996) Technology and market structure, European Economic Review, 40: 511-530.

Wooldridge, J. M. 2002. Econometric Analysis of Cross Section and Panel Data. Cambridge, MA: MIT Press. 


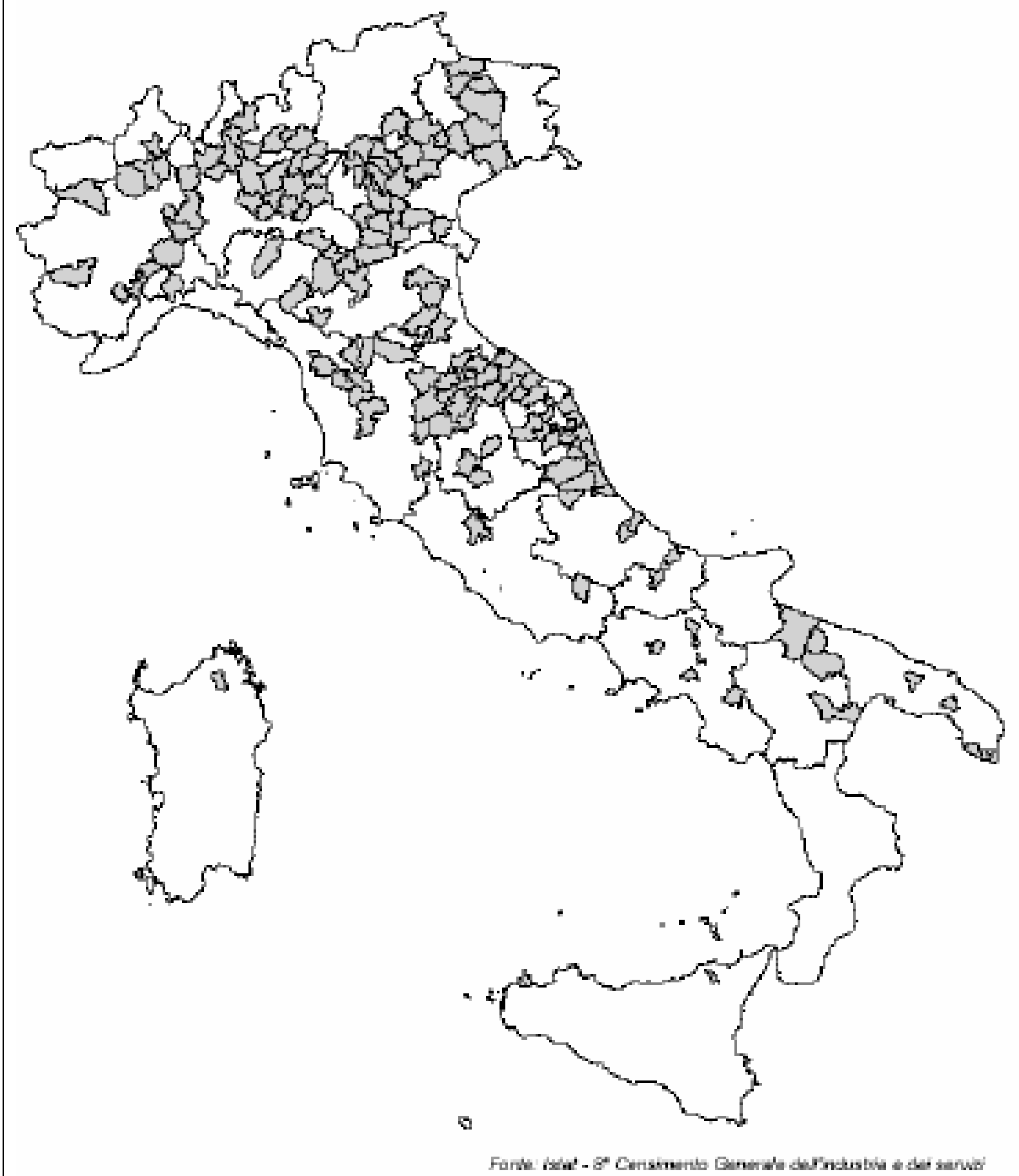

Source: ISTAT 
Figure 1B FDI penetration in Italy by NUTS 2 region

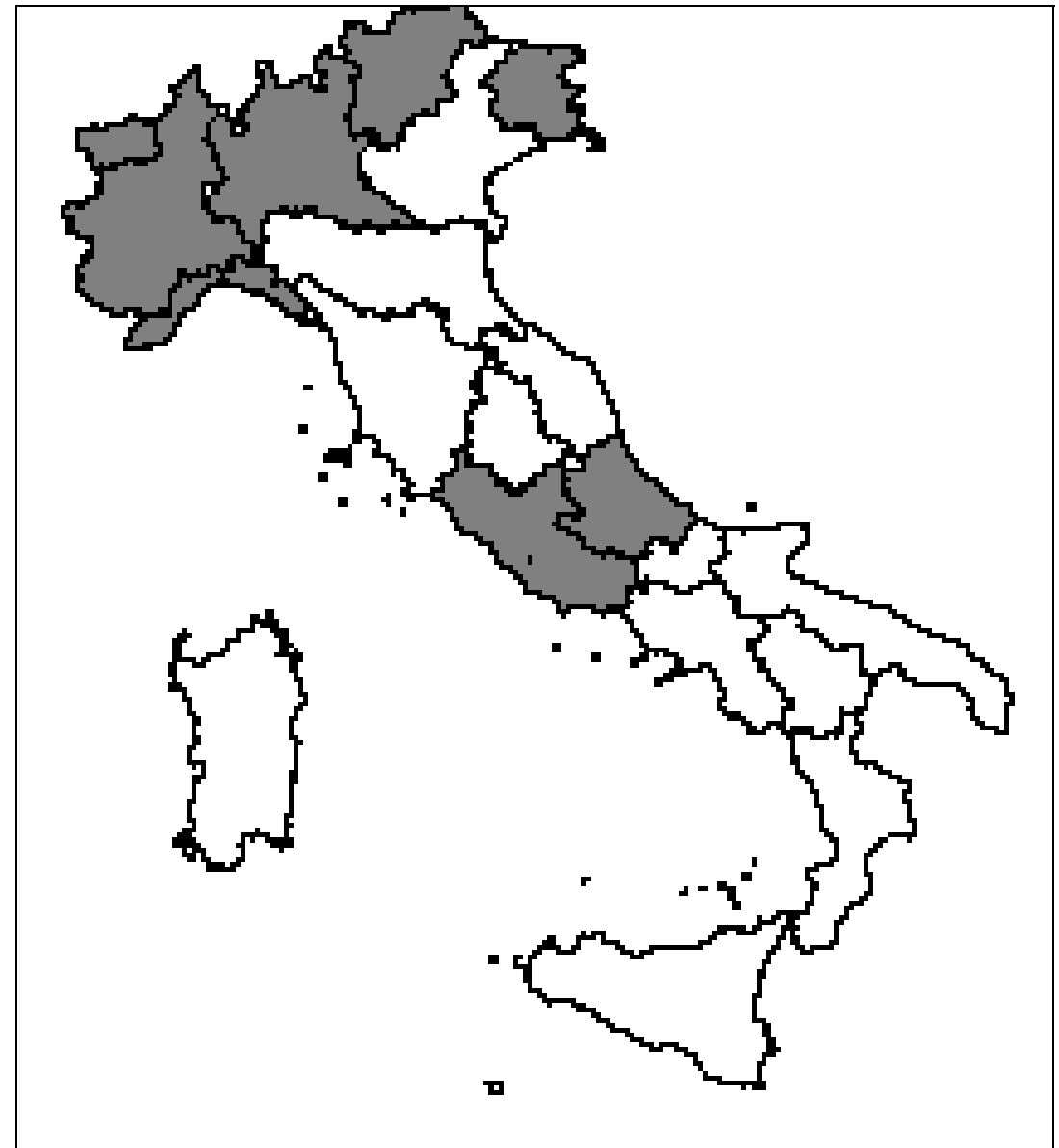

Note: dark regions have high FDI; white regions have low FDI.

Source: Polytechnic University of Milan. 
Table 1: Definitions of the variables included analysis

\begin{tabular}{|c|c|}
\hline \multicolumn{2}{|r|}{ Variable labels and descriptions } \\
\hline Q & $\begin{array}{l}\text { output measured as value added per annum. This is in real terms ( } 2000 \text { prices }) \text {, deflated using the } \\
\text { appropriate two digit producer price index available at the national level. }\end{array}$ \\
\hline $\mathrm{K}$ & $\begin{array}{l}\text { capital stock as the sum of net investment in real terms (2000 prices) over the previous five years is } \\
\text { used instead with a standard depreciation rate of } 10 \% \text {. }\end{array}$ \\
\hline $\mathrm{L}$ & Employment. The data available do not distinguish between skilled and unskilled workers \\
\hline FSIR & Share of foreign over total employment in the relevant industry and region in the current year \\
\hline FSI & Share of foreign over total employment in the relevant industry across all regions in the current year \\
\hline FSR & Share of foreign over total employment in the relevant region across all industries in the current year \\
\hline AGR & $\begin{array}{l}\text { Regional manufacturing employment as a share of the regional population, normalised by the } \\
\text { national average }\end{array}$ \\
\hline AGIR & $\begin{array}{l}\text { Localisation economies measured in terms of employment by LQ stratified by industry and region. } \\
\text { This is a measure of regional industrial specialisation. }\end{array}$ \\
\hline SIZE & The regional share of national population \\
\hline BID & $\begin{array}{l}\text { This variable is derived by combining AGIR with a dummy variable that identifies the location of (at } \\
\text { least one) MIDs characterised by a dominant presence of medium size firms }\end{array}$ \\
\hline SID & $\begin{array}{l}\text { This variable is derived by combining AGIR with a dummy variable that identifies the location of (at } \\
\text { least one) MIDs characterised by a dominant presence of small size firms. }\end{array}$ \\
\hline
\end{tabular}


Table 2 The static panel data model with spatial dependence

\begin{tabular}{|c|c|c|c|c|}
\hline Variables & $\begin{array}{l}\text { FGLS } \\
\text { heteroscedastic } \\
\text { and AR (1) panel } \\
\text { specific }\end{array}$ & Fixed effects & $\begin{array}{l}\text { Prais-Winsten } \\
\text { regression with cross- } \\
\text { section dependence } \\
\text { and common AR(1) }\end{array}$ & $\begin{array}{l}\text { Prais-Winsten } \\
\text { regression with cross- } \\
\text { section dependence } \\
\text { and panel-specific } \\
\text { AR(1) }\end{array}$ \\
\hline $\mathrm{W}^{*} \mathrm{Q}_{\text {irt }}$ & $0.009(6.78)^{* * *}$ & $0.003(0.023)$ & $0.008(4.57)^{* * *}$ & $0.006(4.59)^{* * *}$ \\
\hline $\mathrm{K}_{\text {irt }}$ & $0.179(26.06)^{* * *}$ & $0.071(3.67)^{* * *}$ & $0.192(12.09)^{* * *}$ & $0.171(8.12)^{* * *}$ \\
\hline $\mathrm{L}_{\text {irt }}$ & $0.758(87.69)^{* * *}$ & $0.786(27.70)^{* * *}$ & $0.734(43.76)^{* * *}$ & $0.761(25.48)^{* * *}$ \\
\hline \multicolumn{5}{|c|}{ FDI spillovers } \\
\hline FSIR $_{\text {irt-1 }}$ & $0.098(4.28)^{* * *}$ & $0.047(0.09)$ & $0.065(0.63)$ & $0.058(1.34)$ \\
\hline $\mathrm{FSI}_{\text {it-1 }}$ & $0.891(26.96)^{* * *}$ & $0.347(2.41)^{* * *}$ & $0.766(4.54)^{* * *}$ & $0.838(8.73)^{* * *}$ \\
\hline $\mathrm{FSR}_{\mathrm{rt}-1}$ & $0.152(3.52)^{* * *}$ & $0.007(0.05)$ & $0.187(1.00)$ & $0.168(1.46)$ \\
\hline \multicolumn{5}{|c|}{ Agglomeration externalities } \\
\hline $\mathrm{AGR}_{\mathrm{rt}}$ & $0.226(19.84)^{* * *}$ & $0.023(0.16)$ & $0.253(6.82)^{* * *}$ & $0.249(6.38)^{* * *}$ \\
\hline $\mathrm{AGIR}_{\text {irt }}$ & $0.086(11.18)^{* * *}$ & $0.065(2.39)^{* *}$ & $0.080(4.30)^{* * *}$ & $0.080(3.92)^{* * *}$ \\
\hline $\mathrm{BIDi}_{\mathrm{rt}}$ & $-0.004(0.33)$ & $0.066(0.733)$ & $0.003(0.16)$ & $0.032(1.59)$ \\
\hline $\mathrm{SIDi}_{\mathrm{rt}}$ & $-0.051(-3.57)^{* * *}$ & $-0.006(0.03)$ & $-0.048(-2.89)$ & $-0.089(-2.84)^{* * *}$ \\
\hline \multicolumn{5}{|l|}{ Other variables } \\
\hline Regional size & $1.602(11.62)^{* * *}$ & $1.200(0.23)$ & $1.780(7.73)^{* * *}$ & $1.804(4.77)^{* * *}$ \\
\hline Time trend & $0.026(11.62)$ & $0.033(7.62)$ & $0.022(2.57)$ & $0.026(2.1)$ \\
\hline $\mathrm{N}$ of Obs & 1477 & 1477 & 1477 & 1477 \\
\hline $\mathrm{N}$ of groups & 316 & 316 & 316 & 316 \\
\hline $\begin{array}{l}\text { Model significance: Wald } \\
\text { chi2(9) }\end{array}$ & $194,563.65 * * *$ & & $7112.03 * * *$ & $332,614.56^{* * *}$ \\
\hline $\mathrm{F}(12,1149)$ & & $141.30 * * *$ & & \\
\hline $\begin{array}{l}\text { Corr }\left(\mathrm{u} \_\mathrm{i}, \mathrm{Xb}\right) \\
\text { Introduction of a spatially } \\
\text { lagged }\end{array}$ & & -0.5422 & & \\
\hline $\begin{array}{l}\text { Variable chi2 }(1)= \\
\text { Test of AR(1) Spatial } \\
\text { dependence: }\end{array}$ & $45.99 * * *$ & & & \\
\hline$\Lambda=0 \mathrm{~F}(1,1598)$ & $328.98 * * *$ & & & \\
\hline
\end{tabular}

Note: Test of regional dependence: $\mathrm{CD}(\mathrm{r}) \sim \mathrm{N}(0,1) 27,26^{* * *}$, and test of industry dependence: $\mathrm{CD}(\mathrm{i}) \sim \mathrm{N}(0,1)=11,02^{* * *}$. 
Table 3 The static panel data model with spatial dependence by North-Central and in Southern regions

\begin{tabular}{lcc}
\hline & Northern-Central regions & Southern regions (a) \\
\hline WQ & $0.007(0.64)$ & $0.019(0.7)$ \\
K & $0.25(7.2)^{* * *}$ & $0.153(6.04)^{* * *}$ \\
L & $0.692(17.2)^{* * *}$ & $0.757(19.47)^{* * *}$ \\
\hline \multicolumn{3}{c}{ FDI effects } \\
\hline FSIR & $0.149(2.99)^{* * *}$ & $-0.11(-1.26)$ \\
FSI & $-0.267(-3.56)^{* * *}$ & $0.649(3.23)^{* * *}$ \\
\hline & $0.606(14.05)^{* * *}$ & $1.011(15.64)^{* * *}$ \\
\hline AGR & Agglomeration effects & \\
AGIR & $0.042(1.75)^{*}$ & $0.442(2.99)^{* * *}$ \\
SID & $0.076(3.55)^{* * *}$ & $0.037(1.32)$ \\
BID & $-0.011(-0.62)$ & $-0.142(-4.77)^{* * *}$ \\
\hline Additional effects & $-0.007(-0.72)$ & $0.101(2.62)^{* * *}$ \\
\hline Regional size & & $3.574(5.51)^{* * *}$ \\
time trend & $2.484(5.28)^{* * *}$ & $0.03(1.65)^{*}$ \\
cons & $0.022(2.49)^{* * *}$ & $5.432(10.66)^{* * *}$ \\
\hline N of obs & $3.489(20.02)^{* * *}$ & 128 \\
N of groups & 900 & $835.14 * * *$ \\
Model significance: & 188 & \\
Wald chi2 & $1635.76^{* * *}$ & \\
\hline (a) Sourthern regions exch &
\end{tabular}

(a) Sourthern regions exclude the two major Islands

Table 4 Dividing the sample by FDI penetration

\begin{tabular}{lcc}
\hline & & \\
& High FDI penetration & Low FDI penetration \\
\hline $\mathrm{Q}$ & $-0.003(-0.24)$ & $0.002(1.17)$ \\
$\mathrm{K}$ & $0.244(6.65)^{* * *}$ & $0.158(6.95)^{* * *}$ \\
$\mathrm{~L}$ & $0.704(18.31)^{* * *}$ & $0.745(18.65)^{* * *}$ \\
\hline \multicolumn{3}{c}{ FDI effects } \\
\hline FSIR & $0.112(2.1)^{* *}$ & $-0.032(-0.46)$ \\
FSR & $-0.299(-3)^{* * *}$ & $1.001(2.83)^{* * *}$ \\
FSI & $0.702(12.67)^{* * *}$ & $0.923(7.01)^{* * *}$ \\
\hline \multicolumn{3}{c}{ Agglomeration effects } \\
\hline AGR & $0.048(1.4)$ & $0.336(9.5)^{* * *}$ \\
AGIR & $0.062(2.46)^{* * *}$ & $0.098(4.08)^{* * *}$ \\
SID & $-0.08(-2.51)^{* * *}$ & $-0.092(-5.21)^{* * *}$ \\
BID & $0.032(2.51)^{* * *}$ & $0.054(6.88)^{* * *}$ \\
\hline Additional effects & & \\
\hline regional size & $2.182(4.86)^{* * *}$ & $2.95(8.3)^{* * *}$ \\
time trend & $0.02(2.46)^{* * *}$ & $0.029(2.37)^{* * *}$ \\
cons & $3.652(20.69)^{* * *}$ & $3.713(46.24)^{* * *}$ \\
\hline N of obs & 578 & 899 \\
N of groups & 124 & 192 \\
Model significance: & $725.85 * * *$ & $1329.05^{* * *}$ \\
Wald chi2 & & \\
\hline
\end{tabular}


Table 5 Interactions between FDI and different forms of agglomeration

\begin{tabular}{lccc}
\hline \multicolumn{4}{c}{ (5A) Italy and breakdown by North and South of Italy } \\
\hline & ITALY & NORTH & SOUTH \\
\hline AGR*FSIR & $-0.197(-2.63)^{* * *}$ & $-0.135(-1.27)$ & $-0.546(-2.34)^{* *}$ \\
AGIR*FSIR & $0.092(2.26)^{* *}$ & $0.052(1.2)$ & $-0.023(-0.33)$ \\
SID*FSIR & $0.588(7.63)^{* * *}$ & $0.429(4.81)^{* * *}$ & $-4.093(-1.27)$ \\
BID*FSIR & $0.250(2.26)^{* *}$ & $0.353(3.25)^{* * *}$ & $1.587(0.47)$ \\
\hline
\end{tabular}

(5B) Breakdown by manufacturing intensity and FDI penetration

\begin{tabular}{|c|c|c|c|c|}
\hline & High FDI & Low FDI & High AGR & Low AGR \\
\hline AGR*FSIR & $-0.254(-2.26)^{* *}$ & $-0.139(-1.24)$ & $-0.211(-0.97)$ & $-0.482(-2.53) * * *$ \\
\hline AGIR*FSIR & $0.034(0.72)$ & $0.115(0.51)$ & $-0.283(-2.41)^{* *}$ & $0.135(2.39)^{* *}$ \\
\hline SID*FSIR & $1.100(8.4)^{* * *}$ & $0.564(0.67)$ & $0.419(4.58)^{* * *}$ & $-1.509(-1.3)$ \\
\hline BID*FSIR & $0.238(2.64)^{* * *}$ & $0.274(0.35)$ & $0.427(3.64)^{* * *}$ & $-0.082(-0.54)$ \\
\hline \multicolumn{5}{|c|}{ (5C) Breakdown by type of regions } \\
\hline & $\mathrm{A}$ & $\mathrm{B}$ & $\mathrm{C}$ & $\mathrm{D}$ \\
\hline AGR*FSIR & $\begin{array}{c}0.699(2.38)^{* *} \\
-0.415\left(^{-}\right.\end{array}$ & $-0.169(-0.76)$ & $-1.38(-1.81)^{*}$ & $-0.454(-1.33)$ \\
\hline AGIR*FSIR & $2.65)^{* * *}$ & $0.48(2.1)^{* *}$ & $-0.096(-0.35)$ & $0.122(2.02)^{* *}$ \\
\hline SID*FSIR & $0.783(1.87)^{*}$ & $0.172(0.23)$ & $-3.504(-1.34)$ & $2.659(2.2)^{* *}$ \\
\hline BID*FSIR & $0.249(2.3)^{* *}$ & $0.373(0.47)$ & $1.472(0.48)$ & $0.368(1.43)$ \\
\hline
\end{tabular}


Figure2 Interactions between FDI and agglomeration

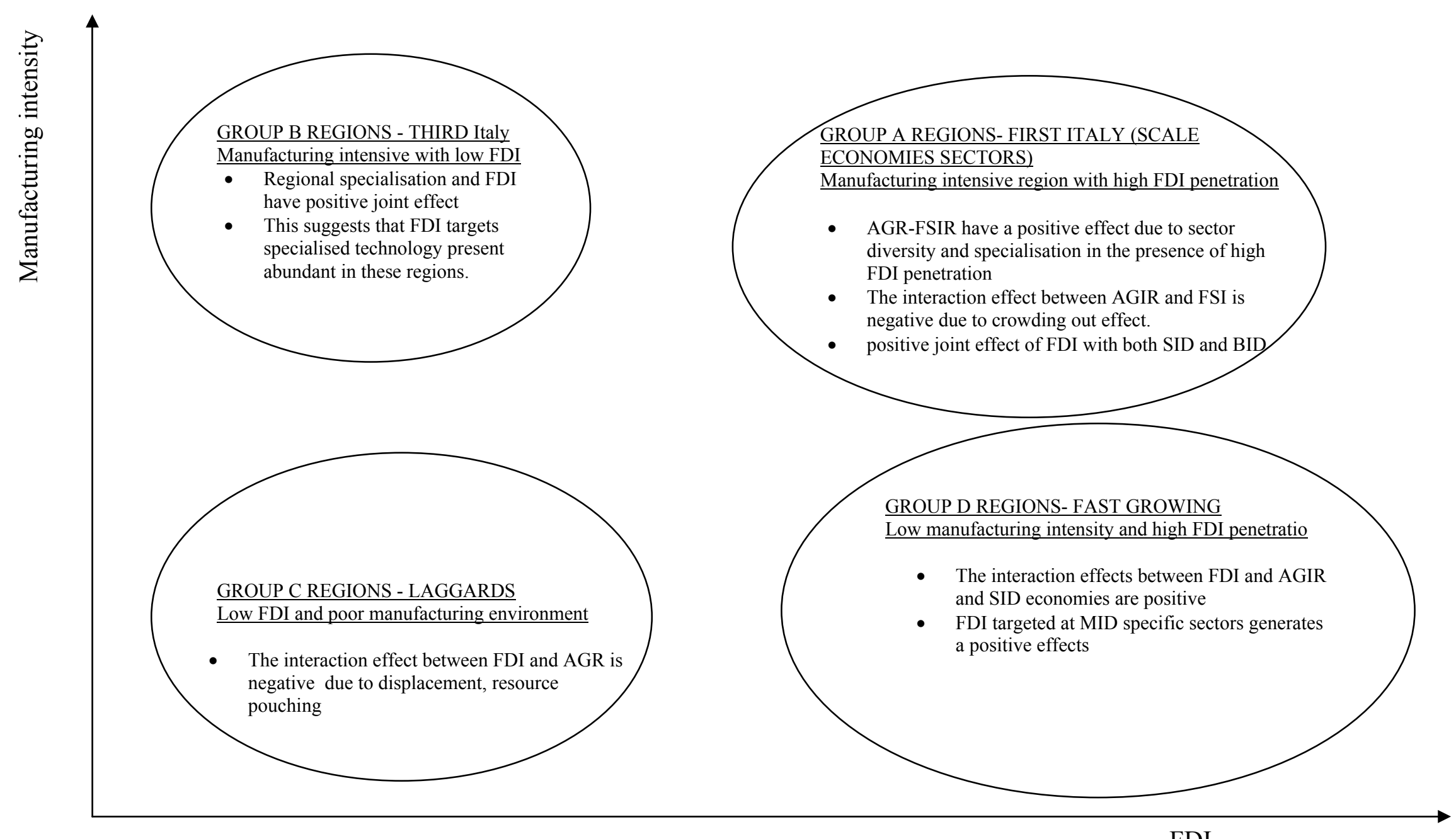

FDI 
Appendix 1 Correlation matrix

\begin{tabular}{|l|r|r|r|r|r|r|r|r|r|l|}
\hline & \multicolumn{1}{|c|}{ WQ } & \multicolumn{1}{c|}{ K } & \multicolumn{1}{c|}{ L } & \multicolumn{1}{c|}{ FSIR } & FSR & FSI & AGR & AGIR & SID & BID \\
\hline WQ & & & & & & & & & & \\
\hline K & 0.2561 & & & & & & & & & \\
\hline L & 0.2954 & 0.8884 & & & & & & & & \\
\hline FSIR & 0.1979 & 0.126 & 0.0802 & & & & & & & \\
\hline FSR & 0.2914 & -0.054 & -0.046 & 0.3083 & & & & & & \\
\hline FSI & 0.0465 & 0.1882 & 0.0233 & 0.3306 & -0.009 & & & & & \\
\hline AGR & 0.5401 & 0.5131 & 0.5458 & 0.102 & 0.0609 & 0.0024 & & & & \\
\hline AGIR & -0.144 & 0.2914 & 0.2505 & -0.021 & -0.002 & -0.017 & -0.123 & & & \\
\hline SID & 0.1183 & 0.2066 & 0.333 & -0.125 & -0.056 & -0.208 & 0.1638 & 0.3012 & & \\
\hline BID & 0.1542 & 0.2425 & 0.3294 & -0.045 & -0.022 & -0.162 & 0.2573 & 0.2599 & 0.6768 & \\
\hline Size & -0.004 & 0.5516 & 0.5818 & 0.0476 & 0.0176 & 0.0053 & 0.252 & 0.0065 & 0.1066 & 0.0591 \\
\hline
\end{tabular}

Appendix 2 The breakdown of regions by FDI and agglomeration.

\begin{tabular}{|l|l|c|c|c|}
\hline \multirow{2}{*}{ Italian regions NUTS2 } & \multicolumn{1}{|c|}{ Macro-regions } & Degree of FDI & Degree of AGR & Type \\
\hline Abruzzo & Southern regions & High FDI & Low AGR & D \\
\hline Basilicata & Southern regions & Low FDI & Low AGR & C \\
\hline Calabria & Southern regions & Low FDI & Low AGR & C \\
\hline Campania & Southern regions & Low FDI & Low AGR & C \\
\hline Emilia Romagna & North-central regions & Low FDI & High AGR & B \\
\hline Friuli-Venezia Giulia & North-central regions & High FDI & High AGR & A \\
\hline Lazio & North-central regions & High FDI & Low AGR & D \\
\hline Liguria & North-central regions & High FDI & Low AGR & D \\
\hline Lombardia & North-central regions & High FDI & High AGR & A \\
\hline Marche & North-central regions & Low FDI & High AGR & B \\
\hline Molise & Southern regions & Low FDI & Low AGR & C \\
\hline Piemonte & North-central regions & High FDI & High AGR & A \\
\hline Puglia & Southern regions & Low FDI & Low AGR & C \\
\hline Sardegna & Southern regions & Low FDI & Low AGR & C \\
\hline Sicilia & Southern regions & Low FDI & Low AGR & C \\
\hline Toscana & North-central regions & Low FDI & High AGR & B \\
\hline Trentino-Alto Adige & North-central regions & High FDI & Low AGR & D \\
\hline Umbria & North-central regions & Low FDI & High AGR & B \\
\hline Valle d'Aosta & North-central regions & High FDI & Low AGR & D \\
\hline Veneto & North-central regions & Low FDI & High AGR & B \\
\hline
\end{tabular}

